\title{
Seed banking of Polish endangered plants - the FlorNatur Project
}

\author{
Jerzy Puchalski*, Maciej Niemczyk, Piotr Walerowski, \\ Wiesław Podyma \& Adam Kapler
}

Polish Academy of Science Botanical Garden - Center for Biological Diversity Conservation in Powsin, Prawdziwka 2, 02-973 Warsaw, Poland

* corresponding author (e-mail: bgpas@obpan.eu)

\begin{abstract}
Among the 2750 species of the Polish vascular flora, about 500 species are threatened with extinction and 430 of them are strictly protected by national law. The FlorNatur project for the ex situ conservation of the most endangered species was started in 2009. The aim of the project is to collect seeds of 61 species from 161 sites in eastern Poland and store them in the Seed Bank of the Polish Academy of Sciences Botanical Garden - Center for Biological Diversity Conservation in WarsawPowsin. A complementary program is being carried out by the Forestry Gene Bank at Kostrzyca in western Poland. Their task is to collect 58 species from 129 natural sites in the western part of Poland. To date, seeds of 31 species from 56 populations have been collected, tested and stored in liquid nitrogen.
\end{abstract}

Key words: seedbank, threatened plants, Polish flora, cryo-conservation, ex situ conservation, dormancy, Fritillaria meleagris

\section{Introduction}

Strict area protection is a commonly used method for the preservation of endangered species (Pimm \& Lawton 1998; Bruner et al. 2001; Brooks 2004). Paradoxically sometimes it leads to local extinction or significant decreases in the numbers of some rare species due to secondary succession (habitat evolution), and the altering of open habitats suitable for protected species into more shady forest habitats (Michalik 1990; Kucharczyk \& Kucharczyk 2008).

Well known examples are the Adenophora liliifolia Bess. population from the Kampinos National Park, the Thymus praecox Opiz population from the Ojców National Park and the Pulsatilla patens (L.) Mill. population from the Białowieża National Park, which significantly decreased in number. The observed habitat changes were as follows: light oak wood supporting A. liliifolia changed into shady lime-hornbeam forest (Rapa 2009, 2011; Otręba et al. 2010; Plan Ochrony KPN 2012); light Cladonio-Pinetum pine forest suitable for abundant $P$. patens stands evolved into dark pine forest (Karczewska 2009; Okołów 2012); and open limestone grasslands supporting T. praecox become dark thickets (Sołtys-Lelek \& Barabasz-Krasny 2009). Habitat change also led to the total disappearance of Saxifraga hirculus (L.) Scop. from wet meadows at the Białowieża NP and Dracocephalum ruyschiana L. from the Wigry National Park (Romański M. - pers. communication 2010; Okołów 2012).

In the cases of the rare plant species mentioned above, ex situ conservation is a necessary conservation strategy to augment populations that are declining and/ or to restore lost, historic localities (Rapa 2009, 2011; Karczewska 2009; Sołtys-Lelek \& Barabasz-Krasny 2009; Otręba et al. 2010; Okołów 2012; Plan Ochrony KPN 2012).

Conservation outside of natural localities is also very important in the case of endangered plant species occurring in unprotected areas eg.: Carex secalina Wahl. from pastures, meadows and cattle pond edges at Kujavia, Ligularia sibirica Cass. from the Pakosław mire, etc. (Olaczek 2004; Żukowski et al. 2005; Nowak et al. 2008; Nobis \& Piwowarczyk 2008; Tabor \& Tabor 2009; Lembicz et al. 2009, 2011).

The Seed Bank in the Polish Academy of Sciences Botanical Garden - Center for Biological Diversity Conservation in Warsaw-Powsin (PAS BG-CBDC) 
was established in 1991 for long-term seed storage studies. The main goal of the Department of Plant Biodiversity Research and Conservation of PAS BG is collecting and preserving the gene pools of the rarest and most endangered populations of the native Polish flora, primarily, species listed on the National Red List (Zarzycki \& Szelag 2006) or regional Red Data Lists, such as Kucharczyk \& Wójciak (1995), Żukowski \& Jackowiak (1995), Kącki et al. (2003), Jackowiak et al. (2007), Nowak et al. (2008) etc.

Whereas most European seed banks use low temperatures, $-20^{\circ} \mathrm{C}$ and drying technology (Gómez-Campo 1972; Puchalski 2004; Pérez-García et al. 2007), the authors use ultra-low temperature storage in liquid nitrogen for long-term germplasm preservation. This method is rather uncommon for plant materials, however, cryopreservation of seeds and spores has become more and more popular in such countries as the US, Australia, Japan and Russia (Puchalski et al. 2010; Voronkova \& Kholina 2010; Ashmore et al. 2011). Cooling generally enhances dry seed longevity and cryopreservation may ensure long-term (10-100 years) storage of short-lived orthodox seeds (Walters et al. 2004; Pritchard \& Nadarajan 2008). Studies carried out at the PAS BG-CDBC have shown that cryopreservation is a reliable storage method. For example, seeds from 12 endangered Polish species (e.g. Polemonium coeruleum L., Linum flavum L., L. austriacum L., Leontopodium alpinum Cass.) have maintained their viability during 10 years of cryostorage (Muranyi unpublished).

The main advantages of ultra low temperature storage technology are:
1) Reduction of biological activity and seed aging rate - the lower temperature of seed storage results in prolonged life of the seeds. Work on dry lettuce seeds has suggested half-lives of 500-3400 years in cryostorage (vapour-phase and liquid-phase) (Walters et. al. 2004).

2) Reduction in the need for regeneration - the method can decrease risks related to seed regeneration. When viability of collected seeds fall to "regeneration standard" it is necessary to generate new seed lots. This involves risks to the genetic integrity of the accessions due to selection, genetic drift or hybridization. Because seeds need to be regenerated less often, cryopreservation reduces the risks connected with this process and allows maintenance of genetic fidelity (Engelmann 2004; Ashmore et al. 2011; Puchalski et al. 2014a, 2014b).

The method is particularly suitable and is recommended for seed storage of endangered or endemic species for which only small amounts of seeds are available (Pérez-García 2008; Ensconet 2009).

\section{Material and methods}

The "Ex situ conservation of wild endangered and protected plants in Eastern Poland - FlorNaturOB" project encompasses many activities, and uses a combination of different approaches tailored for particular purposes. The major objectives of the project are longterm ex situ plant conservation through seed banking, seed biology research and establishment of field collec-

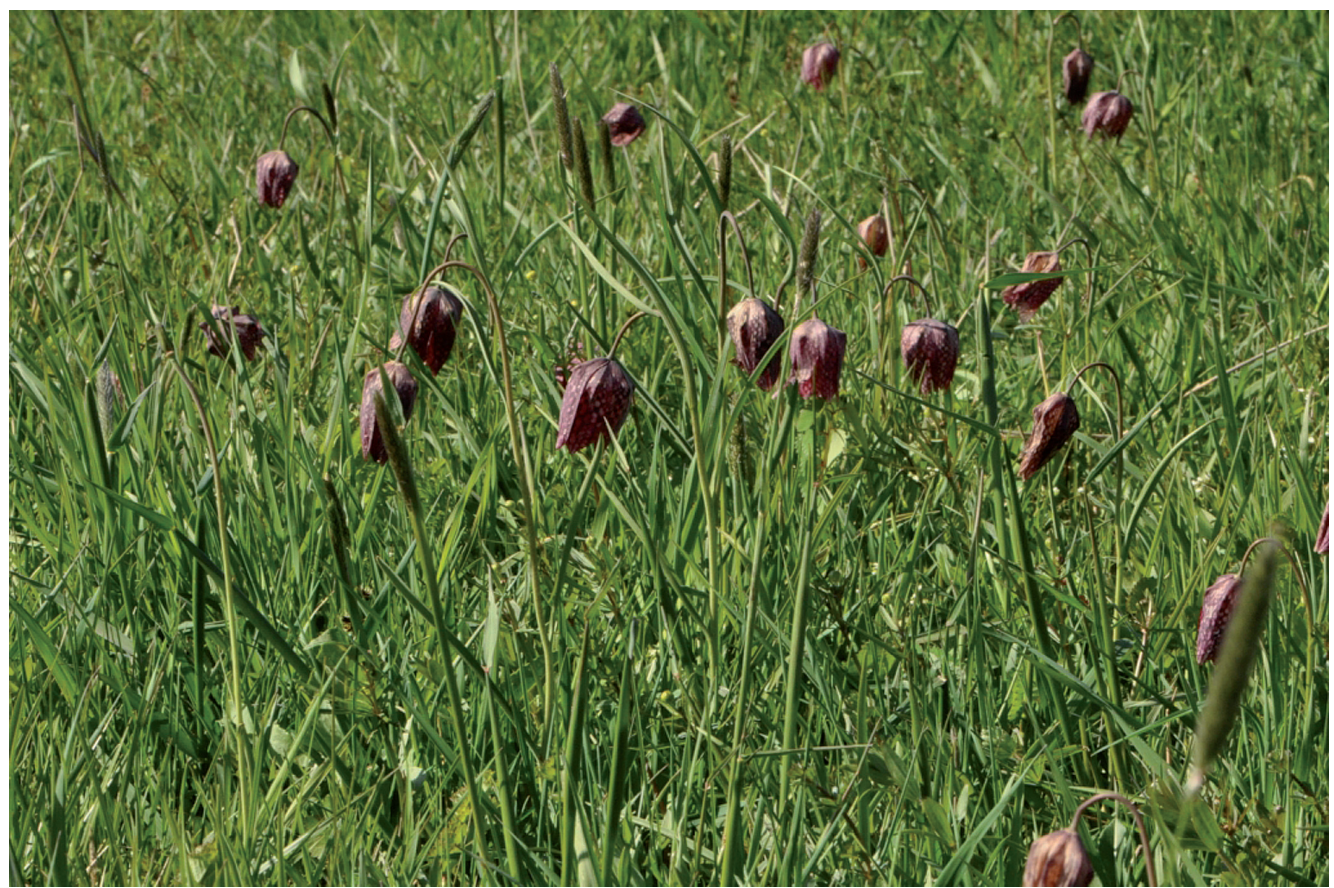

Fig. 1. Fritillaria meleagris L. in the "Krówniki" reserve (photograph by Arkadiusz Nowak) 

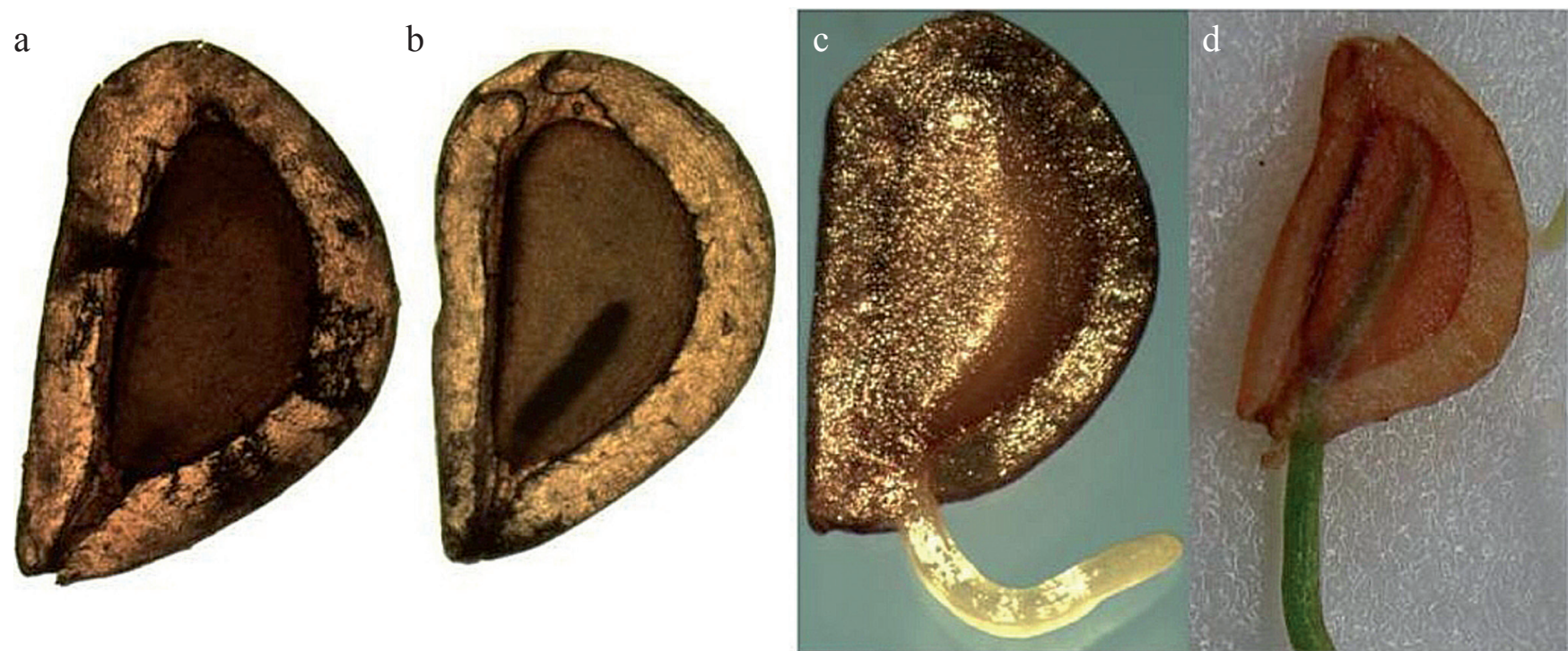

Fig. 2. Stages of Firitillaria meleagris germination

Explanations: $\mathrm{a}-$ fresh seed, $\mathrm{b}$ - seed during storage in $7^{\circ} \mathrm{C}$ (visible embryo), $\mathrm{c}-$ seed germination, $\mathrm{d}-$ seedling

tions at Powsin Botanical Garden. We use the following procedures:

- monitoring and detailed documentation of natural localities of threatened native plants (photographic, phytosociological, climatic and soil parameters),

- seed collecting (according to the ENSCONET manual. See http://ensconet.maich.gr/PDF/Collecting protocol_English.pdf),

- seed cleaning and desiccation,

- viability and freezing tolerance tests (according to PAS BG CBDC' original methods, see below),

- long-term storage in LN2 (according to PAS BG CBDC' unique methods, see below).

The methods were developed and adapted for statutory PAS BG CBDC' conservation tasks (Graniszewska et al. 2004; Puchalski et al. 2010) and in "FlorNaturLBG" project (Gugała 2010; Jałowska 2011).

Seed germination tests are the first step for long-term seeds storage in PAS BG-CBDC. The main aim of these tests is seed viability evaluation. It is very important to know seed viability before seeds are deposited in the seed bank. Germination tests also give us information about the biology of germination (dormancy, required temperatures etc.). That information can be useful in the future for eventual reintroduction projects.

When a seed sample is viable and tolerates freezing to liquid nitrogen temperatures (this factor is evaluated in different experiments) it can be stored in the cryobank.

\section{Results}

For the species whose seeds have been collected since 2010, 18 have been identified as dormant, 6 as partially dormant and 26 as non-dormant (Table 1). Nondormant seeds are mostly associated with thermophilous oakwood and grassland habitats, for example the Potentillo albae-Quercetum Libb., Festuco-Brometea Br.-B1. et R. Tx. and Dendranthemo-Seslerietum variae Grodz. et Jas. in Dzwonko et Grodz. communities.

In most cases dormancy was broken successfully by using 400 ppm giberellic acid (GA3). Stratification was the optimal method for 5 species (mainly partlydormant species, e.g. Saxifraga hirculus L.). There were also 5 species producing hard coated seeds (Allium rotundum L., Dictamnus albus L., Oxytropis pilosa DC., Scheuchzeria palustris L. and Stipa joannis Čelak.) that germinated after scarification and water imbibition. $A$. rotundum, D. albus, and $O$. pilosa were scarified by chipping the seed coat by scalpel, $S$. palustris by rubbing with sandpaper. $S$. joannis required the removal of the covering structure.

A particularly interesting group was the species with specific germination temperature requirements. Allium victorialis L., Fritillaria meleagris L., Muscari comosum Mill., Scandix pecten-veneris L. and Ranunculus arvensis $\mathrm{L}$. did not germinate under the standard germination temperatures used in the PAS BG-CBDC seed bank, i.e. $25^{\circ} \mathrm{C} / 15^{\circ} \mathrm{C}$ (16h light/ $8 \mathrm{~h}$ darkness). $A$. victorialis germinated at a constant temperature of $22^{\circ} \mathrm{C}$ (16h light/ 8h darkness). F. meleagris, $M$. comosum, $S$. pecten-veneris and $R$. arvensis germinated in darkness at temperatures below $10^{\circ} \mathrm{C}$.

Most interesting of all was the germination biology of $F$. meleagris. Seeds of this species did not germinate at $25^{\circ} \mathrm{C} / 15^{\circ} \mathrm{C}$ (16h light/ $8 \mathrm{~h}$ darkness) or at constant temperature $7^{\circ} \mathrm{C}$ (24h darkness) - even with addition of GA3. In order to germinate them it was necessary to 
Table 1. Dormancy and its breaking for the "FlorNaturOB" species

\begin{tabular}{|c|c|c|c|c|c|c|}
\hline & \multirow{2}{*}{ Taxon } & \multirow{2}{*}{ Natural locality } & \multirow{2}{*}{ Dormancy } & \multicolumn{3}{|c|}{ Optimal method for dormancy breaking } \\
\hline & & & & Stratification & $\mathrm{GA}_{3}$ & Scarification \\
\hline 1 & Aconitum sp. & $\begin{array}{l}\text { Bieszczadzki NP, Grojec, Gilowice, Matyska, } \\
\text { Pilsko, Śnieżnik, Babiogórski NP, Cergowa Góra }\end{array}$ & $\mathrm{D}$ & & & \\
\hline 2 & Adenophora lilifolia & Krzemionki Opatowskie, Kisielany & $\mathrm{P}$ & & & \\
\hline 3 & Agrimonia pilosa & Wigierski NP., & $\mathrm{N}$ & & & \\
\hline 4 & Allium rotundum & $\begin{array}{l}\text { Wola Zagojska, Charsznica, Jędrzejów, Busko } \\
\text { Zdrój }\end{array}$ & $\mathrm{D}$ & & & $\mathrm{Sc}$ \\
\hline 5 & Allium victorialis & Environs of Ustrzyki Górne, Glinianka & $\mathrm{N}$ & & & \\
\hline 6 & Arabis recta & Wały, near Broniny, Wola Zagojska & $\mathrm{N}$ & & & \\
\hline 7 & Artemisia pontica & Miechów, Pińczów, Trzebinia & $\mathrm{N}$ & & & \\
\hline 8 & Betula nana & Linje & $\mathrm{D}$ & & & \\
\hline 9 & Campanula serrata & Tatrzański NP, environs of Ustrzyki Górne & $\mathrm{D}$ & & & \\
\hline 10 & Carex pediformis & $\begin{array}{l}\text { Wdowie Skały, Dolina Będkowska, Grodzisko, } \\
\text { Krzyżowa }\end{array}$ & $\mathrm{N}$ & & & \\
\hline 11 & Carex secalina & Dulsk, Turzany, Jacewo, Złotniki Kujawskie & $\mathrm{N}$ & & & \\
\hline 12 & Carlina onopordifolia & Pińczów & $\mathrm{N}$ & & & \\
\hline 13 & Cerastium alpinum & Babiogórski NP & $\mathrm{D}$ & & & \\
\hline 14 & Cochlearia polonica & Centuria, Rajecznica & $\mathrm{N}$ & & & \\
\hline 15 & Dendranthema zawadzkii & Pieniński NP & $\mathrm{N}$ & & & \\
\hline 16 & Dictamnus albus & Kulin, Grabowiec & $\mathrm{D}$ & & & $\mathrm{Sc}$ \\
\hline 17 & Dracocephalum ruyschiana & Biebrzański NP, Puszcza Knyszyńska & $\mathrm{D}$ & & & \\
\hline 18 & Eleocharis carniolica & Environs of Ustrzyki Górne & $\mathrm{D}$ & & & \\
\hline 19 & Erysimum pieninicum & Pieniński NP & $\mathrm{N}$ & & & \\
\hline 20 & Euphorbia epithymoides & Podwarpie, Bukowa Góra & $\mathrm{D}$ & & & \\
\hline 21 & Euphorbia palustris & Tyszowce & $\mathrm{D}$ & & & \\
\hline 22 & Fritillaria meleagris & Krówniki, Stubno & $\mathrm{N}$ & & & \\
\hline 23 & Galium cracoviense & Olsztyn & $\mathrm{N}$ & & & \\
\hline 24 & Galium valdepilosum & Dąbie, Wały, Kalina-Lisiniec & $\mathrm{N}$ & & & \\
\hline 25 & Irys aphylla & Czumów, Izbica, Podgrodzie & $\mathrm{N}$ & & & \\
\hline 26 & Kickxia elatine & Krzanowice, Nowa Wieś Królewska & $\mathrm{P}$ & & & \\
\hline 27 & Ligularia sibirica & Pakosław, Bagno Serebryskie, Roskosz, Brzeźno & $\mathrm{P}$ & & & \\
\hline 28 & Lindernia procumbens & Biała Nyska & $\mathrm{D}$ & & & \\
\hline 29 & Minuartia setacea & Pieniński NP & $\mathrm{N}$ & & & \\
\hline 30 & Muscari comosum & Wrocław & $\mathrm{N}$ & & & \\
\hline 31 & Ostericum palustre & Zwierzyniec, Terlików, Dolina Łabuńki & $\mathrm{P}$ & & & \\
\hline 32 & Oxytropis pilosa & Skorocice, Wola Zagojska & $\mathrm{D}$ & & & Sc \\
\hline 33 & Pedicularis palustris & Biebrzański NP, Ostrowiec Świętokrzyski & $\mathrm{D}$ & & & \\
\hline 34 & $\begin{array}{l}\text { Pedicularis sceptrum- } \\
\text { carolinum }\end{array}$ & Biebrzański NP, Antoniówka & $\mathrm{D}$ & & & \\
\hline 35 & Peucedanum alsaticum & Kąty & $\mathrm{N}$ & & & \\
\hline 36 & $\begin{array}{l}\text { Pinguicula vulgaris subsp. } \\
\text { bicolor }\end{array}$ & $\begin{array}{l}\text { Bagno Serebryskie, Brzeźno, Pogoria, Śniatycze, } \\
\text { Kotlina Orawsko-Nowotarska }\end{array}$ & $\mathrm{D}$ & & & \\
\hline 37 & Pulsatilla patens & $\begin{array}{l}\text { Puszcza Augustowska, Berżniki, Sejny, } \\
\text { Myszyniec }\end{array}$ & $\mathrm{N}$ & & & \\
\hline 38 & Pulsatilla pratensis & $\begin{array}{l}\text { Biebrzański NP, Wigierski NP, Puszcza } \\
\text { Knyszyńska }\end{array}$ & $\mathrm{N}$ & & & \\
\hline 39 & Pulsatilla vernalis & Environs of Tuchola & $\mathrm{N}$ & & & \\
\hline 40 & Ranunculus arvensis & Niemodlin, Opole & $\mathrm{N}$ & & & \\
\hline 41 & Rhododendron luteum & Kołacznia, Ciechanowiec & $\mathrm{N}$ & & & \\
\hline 42 & Saxifraga hirculus & $\begin{array}{l}\text { Biebrzański NP, Wigierski NP, Szeszupa, Giby, } \\
\text { Rospuda, Krąg }\end{array}$ & $\mathrm{P}$ & & & \\
\hline 43 & Scandix pecten-veneris & Wolbrom, Kielce, Janów, Busko Zdrój, Pilica & $\mathrm{N}$ & & & \\
\hline 44 & Scheuchzeria palustris & $\begin{array}{l}\text { Zabrodzie, Galwica, Jeziorko near Drozdowa, } \\
\text { Supraśl, Nożegary, Klimontek, Smolak Mały }\end{array}$ & $\mathrm{D}$ & & & Sp \\
\hline 45 & Serratula lycopifolia & Skorocice & $\mathrm{N}$ & & & \\
\hline 46 & Stipa joannis (S. pennata) & Skorocice, Skowronno, Przypust, Bałtów & $\mathrm{D}$ & & & Csr \\
\hline 47 & Thymus praecox & Góra Koronna, Dziurawiec, Trzaska, Wieża & $\mathrm{N}$ & & & \\
\hline 48 & Veratrum nigrum & Łabunie, Kąty & $\mathrm{N}$ & & & \\
\hline 49 & Veronica praecox & Gniazdowice, Busko Zdrój, Wola Zagojska & $\mathrm{P}$ & & & \\
\hline 50 & Viola epipsila & Białowieski NP, Wigierski NP & $\mathrm{D}$ & & & \\
\hline
\end{tabular}

Explanations: D - dormant, $\mathrm{N}$ - non-dormant, $\mathrm{P}$ - partially dormant, Stratification - 30 days on moist filter paper in $4^{\circ} \mathrm{C}$, Scarification - chipped with scalpel (Sc), rubbed with sandpaper (Sp) or covering structure removed (Csr) 
Table 2. The optimal conditions for $F$. meleagris germination

\begin{tabular}{|c|c|c|c|c|}
\hline \multirow{2}{*}{$\begin{array}{c}\text { Temperature } \\
\text { requirements }\left({ }^{\circ} \mathrm{C}\right)\end{array}$} & \multirow{2}{*}{$\begin{array}{l}\text { Photoperiod } \\
\text { (day/night) h }\end{array}$} & Temperature $\left({ }^{\circ} \mathrm{C}\right)$ & Chemical treatment & Germination (\%) \\
\hline & & $25^{\circ} \mathrm{C} / 15^{\circ} \mathrm{C}(2 \mathrm{mtb})$ & - & 0 \\
\hline $25 / 15$ & $16 / 8$ & & $\mathrm{GA}_{3}$ & 0 \\
\hline $25 / 15$ & $16 / 8$ & $7^{\circ} \mathrm{C}$ (2 mth) & - & 0 \\
\hline $25 / 15$ & $16 / 8$ & $25^{\circ} \mathrm{C} / 15^{\circ} \mathrm{C}(2 \mathrm{mth})$ & - & 80 \\
\hline $25 / 15$ & $16 / 8$ & $\rightarrow 7^{\circ} \mathrm{C}(3 \mathrm{mth})$ & $\mathrm{GA}_{3}$ & 85 \\
\hline
\end{tabular}

apply alternate temperatures $25^{\circ} \mathrm{C} / 15^{\circ} \mathrm{C}(16 \mathrm{~h}$ light/ $8 \mathrm{~h}$ darkness) for 2 months and then $7^{\circ} \mathrm{C}$ ( $24 \mathrm{~h}$ darkness) for 3 months. This unusual photoperiod pattern resulted in high germination $-80 \%$ (Table 2 ).

\section{Discussion}

Seed dormancy is one of the main problems associated with the germplasm gathered by Powsin' staff. Dormancy is an adaptation to survive unfavorable environmental conditions, too harsh for seedling establishment and/or for plant maturation. Generally the identified forms of dormancy are divided into five classes which are subdivided into levels of dormancy (Baskin $\&$ Baskin 2003). There are five classes of dormancy: physiological (PD), morphological (MD), morphophysiological (MPD), physical (PY), combinational (PY+PD). Our research presented in this paper has led mainly to the development of optimal methodologies for breaking dormancy and achieiving high germination rates. Accurate classification of each species to a specific dormancy class needs wider investigation. Unfortunately, in our case, this was usually impossible because of the small amount of seeds of most of collected accessions. In some cases like Allium rotundum, Oxytropis pilosa and Scheuchzeria palustris we classified their dormancy as physical and for Dictamnus albus and Stipa joannis as combinational (water impermeable seed coat and physiologically dormant embryo).

Unfortunately, nature conservationists, agrobiologists and foresters have limited knowledge about levels and types of wild species dormancy, ecophysiological constraints and the evolutionary origins of this phenomenon (Nikołajewa 1967; Baskin \& Baskin 2003). A good illustration of insufficient knowledge about generative reproduction and seed is the case of Fritillaria meleagris. This rare Atlantic relic of the Polish flora (Piórecki 2001) (Fig. 1) used to be treated as obligatorily dichogamous and out-crossing. Only recently, the observations of Zych \& Stpiczyńska (2012) have shown that selfing is rare, but it does occur, and it can lead to normally developed seeds. 
It is commonly accepted that fresh Fritillaria' seeds have undeveloped embryos (Zhang 1983). The embryo in this genus develops further only when temperatures are low and the seed becomes wet (Fig. 2b). That is the reason why traditional storage methods are not suitable for this species because its seeds quickly lose their viability. Post-dispersal embryo development requires imbibition and the rate of embryo growth increases at ower temperatures. Overall, the temperature preferences for F. meleagris' (as well as other Fritillaries associated with open, moist habitats) germination and seedling recruitment are such that in natural localities germination occurs under snow cover or in late winterearly spring coinciding with the snow melt. Gibberellic acid $\left(\mathrm{GA}_{3}\right)$ does not promote embryo growth and development (Zhang 1983; Carasso et al. 2011).

The results of our $F$. meleagris experiments show astrong correlation with the life cycle of this species in natural sites. Seeds are shed in June, but germination occurs in next year's early spring. That is why optimal germination temperatures are $7^{\circ} \mathrm{C}$, and no germination took place at $25^{\circ} \mathrm{C} / 15^{\circ} \mathrm{C}(16 \mathrm{~h}$ light/ $8 \mathrm{~h}$ darkness $)$. Interestingly, seeds placed directly at $7^{\circ} \mathrm{C}$ on moist filter papers, did not germinate. Seeds germinate only when we preceded $7^{\circ} \mathrm{C}$ germination by $25^{\circ} \mathrm{C} / 15^{\circ} \mathrm{C}(16 \mathrm{~h}$ light/ 8h darkness) imbibition (Table 2). These results show that $F$. meleagris germination in the seed bank is burdensome because we must apply alternate warm $\left(25 / 15^{\circ} \mathrm{C}\right)$ and cold $\left(7^{\circ} \mathrm{C}\right)$ stratification in order to mimic the natural site's conditions in the laboratory.

In some cases, we could try to define species' dormancy or germination requirements (temperature, photoperiod) using what we know about related species. For example most Aconitum and Euphorbia species have deep dormant seeds. In laboratory conditions we can break this dormancy only with gibberellic acid $\left(\mathrm{GA}_{3}\right)$. However, sometimes we found big differences in germination biology within one genus - for example between lowland and mountain species of the Pulsatilla genus.

Most xerothermophilous and dry grassland species tested in the PAS BG-CBDC seed bank (about 80\%) show no dormancy and their germination is quite straightforward. But there are also dry grassland species with dormant seeds e.g. Oxytropis pilosa, Dracocephalum ruyschiana $\mathrm{L}$. On the other hand, most peatland and wet sites' species produce dormant or partly dormant seeds - e.g. Betula nana L., Eleocharis carniolica W. D. J. Koch, Ligularia sibirica Cass., Ostericum palustre Bess., Pedicularis palustris L., Saxifraga hirculus, Viola epipsila Ledeb. But in this group there are also species like Cochlearia polonica Frohl. and Carex secalina which produce non-dormant seeds, that germinate at a wide range of temperatures.

In conclusion, there is not always a clear correlation between a plant's ecology in the wild and its germination biology, so it is necessary to study each collected seed sample.

Acknowledgments. We thank prof. Robert Malinowski for language amendments, we thank the editor and anonymous reviewers for their constructive comments, which helped us to improve this manuscript.

\section{References}

Ashmore S., Hamilton K. \& Offord C. 2011. Conservation technologies for safeguarding and restoring threatened flora: case studies from Eastern Australia. In vitro Cell Dev. Biol. Plant 47: 99-109.

BAskin J. M. \& BAskin C. 2003. New approaches to the study of the Evolution of physical and physiological dormancy, the two most common classes of seed dormancy on Earth. In: G. Nicolas, K. BRAdFord, D. Come \& H. W. Pritchard (eds.). The Biology of Seeds, pp. 371-388. Recent Research Advances. CABI Publishing, Salamanca-Cambridge.

Baskin J. M. \& BAskin C. 2004. A classification system for seed dormancy. Seed Science Research 14(1): 1-16.

Brooks T. M. 2004. Coverage provided by the protected-area system: is it enough?. BioScience 54: 1081-1091.

Bruner A., Gullison R., Rice R. \& da Fonseca G. 2001. Effectiveness of Parks in Protecting Tropical Biodiversity. Science 291(5501): 125-128.
Carasso V., Hay F., Proberta R. \& Mucciarelli M. 2011. Temperature control of seed germination in Fritillaria tubiformis subsp. moggridgei (Liliaceae), a rare endemic of the South-west Alps. Seed Science Research 21(1): 33-38.

Engelmann F. 2004. Plant cyopreservation: progress and prospects. In Vitro Cell. Dev. Biol. Plant 40: 427-433.

ENSCONET. 2009. ENSCONET Curation protocols and standards. Royal Botanic Gardens, Kew.

Gómez-CAMPo C. 1972. Preservation of West Mediterranean members of the Cruciferous tribe Brassiceae. Biological Conservation 4(5): 355-360.

Graniszewska M., Muranyi R. \& Prokopiv A. 2004. Methods of germination and cryogenic storage of rare species seeds from the Ukrainian Carpathians. Visnyk of L'viv University, Series Biology 36: 153-159.

GugaŁA A. 2010. Główne założenia projektu "FlorNatur LBG - Ochrona ex situ zagrożonych i chronionych 
roślin, dziko rosnacych $w$ zachodniej Polsce”. Studia $i$ Materiaty CEPL w Rogowie 12(25): 313-327.

Jackowiak B., Celka Z., Chmiel J., Latowski K. \& Żukowski W. 2007. Red list of vascular flora of Wielkopolska (Poland). Biodiv. Res. Conserv. 5(8): 95-127.

JAŁOWSKA M. 2011. FlorNaturLBG - ex situ conservation of endangered and protected plant species. In: W. WŁOCH (ed.). Back to Eden. Challenges for contemporary gardens, pp.: 33-43. Katowice-Ustron-Mikołów, 21 23.05.2011.

Karczewska M. 2009. Nowe stanowisko Pulsatilla patens (Ranunculaceae) w Białowieskim Parku Narodowym. Fragm. Flor. Geobot. Polonica 16(2): 438-440.

KĄCKi Z., DAJdok Z. \& SzCZęŚniak E. 2003. Czerwona lista roślin naczyniowych Dolnego Śląska. In: Z. KĄCKI (ed.) 2003. Zagrożone gatunki flory naczyniowej Dolnego Śląska, pp. 9-64. Instytut Biologii Roślin U. Wr., Polskie Tow. Przyjaciół Przyrody ,pro Natura”, Wrocław.

KuChARCZyK M. \& WóJCiAK J. 1995. Ginące i zagrożone gatunki roślin naczyniowych Wyżyny Lubelskiej, Roztocza, Wołynia Zachodniego i Polesia Lubelskiego. Ochrona Przyrody 52: 33-46.

Kucharczyk M. \& Kucharczyk H. 2008. Protection of the Lady's Slipper Orchid and Lilyleaf Ladybell versus protection of Natura 2000 habitats. $6^{\text {th }}$ European Conference on Ecological Restoration "Towards a sustainable future for European ecosystems - Providing restoration guidelines for Natura 2000 habitats and species" Ghent, Belgium, 8-12/09/2008, pp. 1-5.

Lembicz M., Bogdanowicz A., Chmiel J. \& Żukowski W. 2009. Carex secalina (Cyperaceae), a critically endangered species of Europe: historic and new localities in Poland. Acta Soc. Bot. Pol. 78(3): 311-320.

Lembicz M., Olejniczak P., Żukowski W. \& Bogdanowicz A. M. 2011. Effect of mother plant age on germination and size of seeds and seedlings in the perennial sedge Carex secalina (Cyperaceae). Flora 206: 158-163.

Michalik S. 1990. Sukcesja wtórna i problem aktywnej ochrony biocenoz półnaturalnych w parkach narodowych i rezerwatach Polski. Prace Muz. Szafera 2: 175-198.

NikoŁAJewa M. G. 1967. Fizłologija głubokogo pokoja siemjan. Izdatielstvo Nauka, Leningrad.

Nobis M. \& Piwowarczyk R. 2008. The distribution, habitat preferences and size of population of Ostericum palustre Besser on the south-western limit of its occurrence in Poland. Nature Conserv. 65: 43-49.

Nowak A., Nowak S. \& SpaŁek K. 2008. Red list of vascular plants in Opole province. Opole Scient. Soc., Nature Journal 41: 141-158.

Окоєów C. 2012. Białowieski Park Narodowy (1921-2011) - próba bilansu 90-lecia. Chrońmy Przyr. Ojcz. 98(4): 288-301.

Olaczek R. 2004. 1758. Ligularia sibirica (L.) Cass. Języczka syberyjska. In: B. SUDNIK-WósciKowsKa \& H. Werblan-JAKubIEC (ed.). Poradniki ochrony siedlisk i gatunków - podręcznik metodyczny. Gatunki roślin. Tom 9, pp. 140-144. Ministerstwo Środowiska, Warszawa.
Otręba A., Ferchmin M., KębŁowska A., Kloss M. \& Michalska-Hejduk D. 2010. Ochrona flory i roślinności w Kampinoskim PN. In: A. OBIDZIŃSKI (ed.). 2010. Z Mazowsza na Podlasie i Wileńszczyznę. Zróżnicowanie i ochrona szaty roślinnej pogranicza Europy Środkowej i Północno-Wschodniej, pp. 67-94. Polskie Towarzystwo Botaniczne - Zarząd Główny, Warszawa.

Peltzer S. \& Matson P. 2002. Understanding the weed seed bank life of important agricultural weeds. Pp. 21-22. Agrobusiness Crop Updates, Department of Agriculture, Western Australia.

Pérez-García F., GonzÁlez-Benito M. E. \& Gómez-CAmpo C. 2007. High viability recorded in ultra-dry seeds of 37 species of Brassicaceae after almost 40 years of storage. Seed Science and Technology 35(1): 43-153.

Pérez-García F. 2008. Effect of cryopreservation, gibberellic acid and mechanical scarification on the seed germination of eight endemic species from the Canary Islands. Seed Science and Technology 36(1): 237-242(6).

PióReCKI J. 2001. CR Frtillaria meleagris L. - Szachownica kostkowata. In: R. KaźmierczaKowa \& K. ZARZYCKI (eds.). Polska Czerwona Księga Roślin. Paprotniki i rośliny kwiatowe, wyd. 2, pp. 416-18. PAN, Instytut Botaniki im. W. Szafera, Instytut Ochrony Przyrody, Kraków.

Pimm S. \& Lawton J. 1998. Planning for Biodiversity. Science 279(5359): 2068-2069.

Plan Ochrony KPN 2012. Rozporządzenie Ministra Środowiska w sprawie ustanowienia Planu Ochrony dla Kampinoskiego Parku Narodowego z uwzględnieniem zakresu planu zadań ochronnych dla obszaru Natura2000 PLC 140001 Puszcza Kampinoska.

Pritchard H. \& Nadarajan J. 2008. Cryopreservation of Orthodox (Desiccation Tolerant) Seeds. In: B. REED (ed.). Plant Cryopreservation: A Practical Guide, pp 485-501. USDA-ARS National Clonal Repository, Corvallis, USA.

PuChALSKi J. 2004. International programmes for seed preservation of European native plants. Biul. Ogr. Bot. Muz. Zbior. 13: 11-18.

Puchalski J., KAPler A. \& NiemcZyk M. 2010. Ex situ conservation of Polish endangered plant species in botanical gardens. Botanic Gardens and Biodiversity. $200^{\text {th }}$ Anniversary of University Botanic Gardens Ljubljana, European Botanic Gardens Consortium Meeting, Ljubljana, 12-16.05.2010, pp. 160.

Puchalski J., Kapler A., Krzyżewski A., Niemczyk M. \& WALEROWSKi P. 2014a. Crop Wild Relatives as a new target group for research, in situ and ex situ protection measures. Polish Journal of Agronomy (in print).

Puchalski J., Smieja A., Kapler A., Krzyżewski A., Niemczyk M. \& WALERowsKi P. 2014b. Ex situ conservation of Rhododendron luteum Sweet - a critically threatened with extinction, native ornamental plant. Polish Journal of Agronomy (in print).

RAPA A. 2009. 4068 Dzwonecznik wonny Adenophora liliifolia (L.) Besser. Monitoring gatunków i siedlisk przyrodniczych ze szczególnym uwzględnieniem 
specjalnych obszarów ochrony siedlisk Natura2000. Wyniki monitoringu GIOŚ. 11 pp. Generalna Inspekcja Ochrony Środowiska, Warszawa.

RAPA A. 2011. 4068 Dzwonecznik wonny Adenophora liliifolia (L.) Besser. Monitoring gatunków i siedlisk przyrodniczych ze szczególnym uwzględnieniem specjalnych obszarów ochrony siedlisk Natura2000. Wyniki monitoringu GIOŚ. 19 pp. Generalna Inspekcja Ochrony Środowiska, Warszawa.

SaAtkamp A., Affre L., Dutoit T. \& Poschlod P. 2011. Germination traits explain soil seed persistence across species: the case of Mediterranean annual plants in cereal fields. Annals of Botany 107: 415-426.

SoŁtys-Lelek A. \& Barabasz-Krasny B. 2009. Skuteczność dotychczasowych form ochrony roślin i szaty roślinnej w Ojcowskim Parku Narodowym. Ochrona Środowiska i Zasobów Naturalnych 39: 89-102.

SYMONIDES E. 1987. Strategia reprodukcyjna terofitów, mity i fakty. I. Teoretyczny model strategii optymalnej. Wiad. Ekol. 33:103-135.

Symonides E. 1989. Bank nasion jako element strategii reprodukcyjnej terofitów. Wiad. Ekol. 35: 107-144.

TABOR M. \& TABOR J. 2009. Ochrona torfowiska Pakosław. 12 pp. Mazowiecko-Świętokrzyskie Towarzystwo Ornitologiczne, Pionki.

Trzcińska-TACik H. \& Chmiel J. 2001. CR Veronica praecox All. - Przetacznik wczesny. In: R. KAźmierczaKowa \& K. ZARZYCKi (eds.). Polska Czerwona Księga Roślin. Paprotniki i rośliny kwiatowe, wyd. 2, pp. 331-332. PAN, Instytut Botaniki im. W. Szafera, Instytut Ochrony Przyrody, Kraków.
Voronkova N. \& Kholina A. 2010. Conservation of endemic species from the Russian Far East using seed cryopreservation. Biology Bulletin 37(5): 496-501.

Walters C., Wheeler L. \& Stanwood P. C. 2004. Longevity of cryogenically stored seeds. Cryobiology 48 : 229-244.

ZARZYCKI K. \& SZELĄG Z. 2006. Red list of the vascular plants in Poland. In: Z. MireK, K. Zarzycki, W. WojewodA \& Z. SzeląG (eds.). Red list of plants and fungi in Poland, pp. 9-20. W. Szafer Institute of Botany, Polish Academy of Sciences, Kraków.

ZHANG L. 1983. Vegetation ecology and population biology of Fritillaria meleagris L. at the Kungsangen Nature Reserve, Eastern Sweden. Acta Phytogeographica Suecica 73: 1-97.

ZyCh M. \& STPICZYŃSKA M. 2012. Neither protogynous nor obligatory out-crossed: pollination biology and breeding system of the European Red List Fritillaria meleagris L. (Liliaceae). Plant Biol. 14(2): 285-294.

ŻUKOWSKI W. \& JACKOWIAK B. (eds.). 1995. Endangered and threatened vascular plants of Western Pomerania and Wielkopolska. Publications of the Department of Plant Taxonomy of the Adam Mickiewicz University in Poznań 3: 1-141. Bogucki Wyd. Nauk., Poznań.

Żukowski W., Lembicz M., Olejniczak P., Bogdanowicz A., Chmiel J. \& Rogowski A. 2005. Carex secalina (Cyperaceae), a species critically endangered in Europe: from propagule germination to propagule production. Acta Soc. Bot. Pol. 74(2): 141-147. 